\title{
Halitosis and its influence on the quality of life
}

\author{
Halitose e sua influência na qualidade de vida \\ Halitosis y su influencia en la calidad de vida \\ Kátia NUNES ${ }^{1}$ \\ Alexandre CONDE ${ }^{2}$ \\ Juliane Pereira BUTZE ${ }^{3}$ \\ Graduada em Odontologia pela FSG Centro Universitário 95020-472 Caxias do Sul-RS, Brasil \\ ${ }^{2}$ Doutor em Materiais Dentários, Professor do Curso de Odontologia da FSG Centro Universitário, 95020-472 Caxias do Sul - RS, Brasil \\ ${ }^{3}$ Doutora em Periodontia, Professora do Curso de Odontologia da FSG Centro Universitário, 95020-472 Caxias do Sul-RS, Brasil
}

\begin{abstract}
Objectives: To describe the patients' perception of their own breath and verify that halitosis can lead to loss of quality of life of patients with this condition. Methods: A consecutive sample was formed from patients who sought treatment at the Dentistry Screening Service of FSG Centro Universitário, between the months of August 2015 and September 2015, where they answered a questionnaire with objective questions about their perception of breath, and attitudes related to social situations where the breath can be influential. Results: Participated in this survey a total of 102 patients. Of these, 27 (26.5\%) were male and 75 (73.5\%) were female. When asked about the importance and concern for their breath, 95 (94.1\%) participants reported that the smell of breath has great importance in their lives and 96 of these patients (95\%) have a high concern for the own breath. Conclusion: On patients' perceptions, halitosis affects the quality of life of people. However, other studies should be conducted in order to evaluate the influence of halitosis in the quality of life of patients with this condition.
\end{abstract}

Descriptors: Halitosis; Quality of Life; Health Education.

\section{Resumo}

Objetivos: descrever a percepção dos pacientes sobre o seu próprio hálito e verificar se a halitose pode levar à perda de qualidade de vida dos portadores desta condição. Métodos: Uma amostra consecutiva foi formada a partir de pacientes que procuraram atendimento na Clínica de Triagem do curso de Odontologia do Centro Universitário da Serra Gaúcha, entre os meses de Agosto de 2015 e Setembro de 2015, onde os mesmos responderam a um questionário composto por perguntas objetivas sobre a percepção do hálito, além de atitudes relacionadas a situações sociais em que o hálito pode ser influente. Resultados: Participou da pesquisa um total de 102 pacientes. Destes, 27 (26,5\%) eram do sexo masculino e $75(73,5 \%)$ eram do sexo feminino. Quando indagados sobre a importância e preocupação com o hálito, 95 (94,1\%) participantes relataram que o hálito exerce grande importância nas suas vidas e 96 desses pacientes (95\%) possuem uma alta preocupação em relação ao próprio hálito. Conclusão: Na percepção dos pacientes, a halitose tem influência sobre a qualidade de vida dos seus portadores. Porém, outros estudos devem ser conduzidos a fim de se avaliar a influência da halitose na qualidade de vida dos portadores desta condição.

Descritores: Halitose; Qualidade de Vida; Educação em Saúde.

\section{Resumen}

Objetivos: Describir las percepciones de los pacientes sobre su propio aliento y verificar si la halitosis puede conducir a la pérdida de la calidad de vida de los pacientes con esta afección. Métodos: se formó una muestra consecutiva de pacientes que buscaron atención en la Clínica de Cribado de la Facultad de Odontología del FSG Centro Universitario, entre agosto de 2015 y septiembre de 2015, donde respondieron un cuestionario compuesto por preguntas objetivas sobre la percepción de la respiración, así como actitudes relacionadas con situaciones sociales donde la respiración puede ser influyente. Resultados: Un total de 102 pacientes participaron en la investigación. De estos, $27(26.5 \%)$ eran hombres y $75(73.5 \%)$ eran mujeres. Cuando se les preguntó sobre la importancia y la preocupación por su respiración, 95 (94.1\%) participantes informaron que su respiración es de gran importancia en sus vidas y 96 de estos pacientes (95\%) tenían una gran preocupación por su propia respiración. Conclusión: en la percepción de los pacientes, la halitosis influye en la calidad de vida de sus pacientes. Sin embargo, se deben realizar otros estudios para evaluar la influencia de la halitosis en la calidad de vida de los pacientes con esta afección.

Descriptores: Halitosis; Calidad de Vida; Educación en Salud.

\section{INTRODUCTION}

Halitosis or bad breath, as is popularly known, daily affects social and psychological life of individuals affected by this condition ${ }^{1-2}$. Although, the word halitosis is derived from Latin and its meaning is "a pathological change," halitosis is actually considered a symptom and not a disease ${ }^{2-4}$. Halitosis is represented by unpleasant breath or offensive odor as a result of physiological or pathological causes, may be primary (oral) or secondary (systemic) ${ }^{1,5-8}$.

Related to the oral origin causes, we can cite tongue coating, periodontal disease, defective restorations, badly cleaned dentures and even cavities resulting from caries ${ }^{5-7}$. Among the systemic origin causes are the ones represented by nasal passages, gastrointestinal and neurological disorders, systemic diseases and medical drugs ${ }^{5,9}$.

Bad breath has become a matter of concern for much of the population, due to the fact that is a difficult problem to diagnose due to multifactorial causes and for causing disorder in the social, affective and professional life of the individual reflecting on their emotional health ${ }^{3,8,10}$.

This study aimed to describe the patients' perception of their own breath and to verify if halitosis can lead to loss of quality of life of patients with this condition.

\section{MATHERIAL AND METHOD}

The study is characterized as a crosssectional observational where we sought to assess whether the loss of quality of life is associated with halitosis. Data were collected between the months of August 2015 and September 2015, with patients who sought treatment at the Dentistry Clinic Screening Service at the FSG Centro Universitário. This study consisted of a convenience sample, according to the college demand. The study was approved by the Research Ethics Committee of Workers', of Faculty of FSG Centro Universitário (CAAE 45522715.2.0000.5311).

To be eligible, patients must have: age of 18 
years or older and at least 12 teeth in the mouth. Patients with abnormal olfactory capacity as anosmia (lack of smell) and hyposmia (reduction on the capacity of smell), or possessing some cognitive impairment, which made it impossible to understand the purpose of research or to provide reliable information were not included on this study.

Interested and qualified patients dated, initialed and signed then, the Consent and Informed form. A consecutive sample was then formed from patients referred to the Screening Service of the Dentistry of the University Center of Serra Gaúcha, where they answered a questionnaire with objective questions about the perception of breath, and related social situations in which the breath can be influential. The questionnaire used for this conducted study was a questionnaire developed by the Brazilian Association for Studies and Research of Mouth Odors (ABPO), used in the research titled "Bad breath and Quality of Life" performed by the same association $^{11-12 .}$

\section{RESULTS}

Participated in the survey a total of 102 patients who sought dental Screening Service at the FSG Centro Universitário. Of these, 27 (26.5\%) were male and $75(73.5 \%)$ were female. Most of the interviewed patients, $40(39.2 \%)$ were older than 50 years. Regarding to smoking, $86(84.3 \%)$ patients reported not to be tobacco users. On the oral hygiene habits, tooth brushing frequency was 3 times per day $(54.9 \%)$, then 2 times a day (29.4\%), 4 times or more $(11.8 \%)$ and only 1 once daily (3.9\%). It was also possible to see that most of the patients interviewed, $82(80.4 \%)$ have received some kind of oral hygiene orientation and that more than half of them, 51 (51.5\%) applies an average intensity of force during brushing (Table 1).

Table 1- Description of the population studied and characteristic of brushing. Caxias do Sul, 2015.

\begin{tabular}{l|c|c}
\hline & $\mathbf{n}$ & $\mathbf{\%}$ \\
\hline Sex & & \\
Male & 27 & 26,5 \\
Female & 75 & 73,5 \\
Age (years) & 24 & \\
$\leq 29$ & 38 & 23,5 \\
$30-49$ & 40 & 37,3 \\
$\geq 50$ & & 39,2 \\
Tobacco Smoking Habits & 16 & 15,7 \\
Yes & 86 & 84,3 \\
No & & \\
Tooth Brushing Frequency & 4 & 3,9 \\
Once a day & 30 & 29,4 \\
Twice a day & 56 & 54,9 \\
Three times a day & 12 & 11,8 \\
Four or more times a day & & \\
Frequency of flossing & 37 & 36,2 \\
No once a day & 26 & 25,5 \\
Once a day & 10 & 9,9 \\
Twice a day & 05 & 4,9 \\
Three or more times a day & 24 & 23,5 \\
Not answer & \\
\hline
\end{tabular}

The description of the variables associated with the breath and behaviors to avoid bad breath is shown in Table 2, where it is possible to observe that approximately $95(94.1 \%)$ of the participants reported that the breath has great importance in their lives and
96 of these patients (95\%) have a high concern for the own breath. In asking the question "Has anyone ever told you have bad breath", 60 (59.4\%) answered yes and 94 (94\%) believe that people with bad breath should be alerted. However, the majority, or 61 $(61 \%)$ say they only alert someone about their bad breath if they are intimate to the person. More than half of the interviewed patients $(52 \%)$ reported that they have asked someone how was their breath. Regarding the use of mints, gum and / or mouthwash to fight bad breath odor, they were present in 55 (55\%), $45(45.9 \%)$ and $59(59 \%)$ of the responses respectively. Table 3 describes the association between demographic social variables linked to breath in relation to information about the presence of bad breath. By Chi-square test we observed a significant association only in relation to the use of mints.

Table 2- Description of variables associated with breath and behaviors to prevent bad breath. Caxias do Sul, 2015.

\begin{tabular}{|c|c|c|}
\hline & $\mathbf{n}$ & $\%$ \\
\hline \multicolumn{3}{|c|}{ Importance of breath in your life } \\
\hline Very important & 95 & 94,1 \\
\hline Important & 6 & 5,9 \\
\hline Little important & o & 0,0 \\
\hline \multicolumn{3}{|l|}{ Concern about breath } \\
\hline Low & 5 & 5,0 \\
\hline High & 96 & 95,0 \\
\hline \multicolumn{3}{|c|}{ Has anyone ever said that you have bad breath? } \\
\hline Yes & 60 & 59,4 \\
\hline No & 41 & 40,6 \\
\hline \multicolumn{3}{|c|}{$\begin{array}{l}\text { Should people with unpleasant breath be } \\
\text { warned? }\end{array}$} \\
\hline Yes & 94 & 94,0 \\
\hline No & 6 & 6,0 \\
\hline \multicolumn{3}{|c|}{ Have you ever asked someone about your breath? } \\
\hline Yes & 52 & 52,0 \\
\hline No & 48 & 48,0 \\
\hline \multicolumn{3}{|c|}{ If someone has bad breath what do you do? } \\
\hline Always warns & 11 & 11,0 \\
\hline Warn if it's someone close & 61 & 61,0 \\
\hline Offers a flavored bullet & 11 & 11,0 \\
\hline Don’t warn & 17 & 17,0 \\
\hline \multicolumn{3}{|l|}{ Habits } \\
\hline \multicolumn{3}{|l|}{ Flavored bullet use } \\
\hline Yes & 55 & 55,0 \\
\hline No & 45 & 45,0 \\
\hline \multicolumn{3}{|l|}{ Chiclet use } \\
\hline Yes & 45 & 45,9 \\
\hline No & 53 & 54,0 \\
\hline \multicolumn{3}{|l|}{ Mouthwash use } \\
\hline Yes & 59 & 59,0 \\
\hline No & 41 & 41,0 \\
\hline
\end{tabular}

Table 3- Association between sociodemographic and breath-related variables in relation to information about the presence of bad breath. Caxias do Sul, 2015.

\begin{tabular}{|c|c|c|}
\hline & $\begin{array}{l}\text { Told you have } \\
\text { bad breath? }\end{array}$ & $\begin{array}{c}\text { p- } \\
\text { value* }\end{array}$ \\
\hline Sex & & 0,28 \\
\hline Male & 66,7 & \\
\hline Female & 56,8 & \\
\hline Age (years) & & 0,395 \\
\hline$\leq 29$ & 52,2 & \\
\hline $30-49$ & 55,3 & \\
\hline$\geq 50$ & 67,5 & \\
\hline Tobacco Smoking & & 0,350 \\
\hline Yes & 68,8 & \\
\hline No & 57,6 & \\
\hline Have you ever asked about your bad breath? & & 0,187 \\
\hline Yes & 63,5 & \\
\hline No & 57,4 & \\
\hline Flavored bullet use & & 0,023 \\
\hline Yes & 70,9 & \\
\hline No & 46,7 & \\
\hline Chiclet use & & 0,669 \\
\hline Yes & 63,6 & \\
\hline No & 54,7 & \\
\hline Mouthwash use & & 0,268 \\
\hline Yes & 64,4 & \\
\hline No & 53,7 & \\
\hline
\end{tabular}

\section{DISCUSSION}

Although halitosis is not a disease, this 
variation usually causes changes in the behavioral pattern of the individual who possesses it and that these ultimately affect their personal relationships, self-assurance, spontaneity and self-esteem. Emotional health is crucial to all aspects of the individual's life and halitosis carrier turns out to have their emotional health shaken, limiting the quality of life of people affected by this problem ${ }^{12}$.

This study was based on the research titled "Bad breath and quality of life" developed in 2008 by the Brazilian Association of Mouth Odors (ABPO) ${ }^{12}$, current Brazilian Association of Halitosis (ABHA). The findings of this study, turned out to be very similar to the study cited above. Individuals, when asked about the degree of concern with their breath, pointed out a high degree of concern $(95 \%)$ and consequently give much importance to it (94\%).

Elias and Ferriani ${ }^{13}$, studying the historical aspects of halitosis, described that the bad breath has always been considered a source of unhappiness for individuals, mainly for affecting negatively their communication and the pleasures of social contact. According to the authors, the concern with the quality of the breath itself affects self-esteem, selfconfidence and consequently, interpersonal relationships.

In accordance to the findings of $\mathrm{ABPO}^{12}$, the vast majority of the interviewed (94\%) believe that people with unpleasant breath should be warned, however, $61 \%$ of them only warn someone with bad breath if he or she is intimate with that person. Such behavior has been described by Nadanovsky et al. $(2007)^{14}$ highlighting the embarrassment felt by those who live with people with halitosis.

Almas et al. ${ }^{15}$ described the negative interference of halitosis in the professional life of a group of 372 individuals from Saudi Arabia. Sopapornamorn et al. (2006) ${ }^{16}$ reported the fear of patients with halitosis have to talk to others, especially indoors. According to Eli et al. ${ }^{17}$, individuals who complain of halitosis even when it does not exist, often present depression, anxiety and feelings of inferiority.

Considering the concept of quality of life advocated by the World Health Organization ${ }^{18}$, according to which, covers the perception of individuals and their physical, emotional and social dimensions, halitosis can be considered as a negative interference factor in the quality life. However, there are no literature studies that assess the relationship between halitosis and quality of life, probably due to the fact that there is no validated instrument that can associate bad breath and its influence in the lives of individuals with this condition.

\section{CONCLUSION}

From the results obtained, it can be concluded that bad breath interfere significantly in the lives of patients with this condition, according to the reports of the interviewed. However, other studies should be conducted in order to evaluate the influence of halitosis in the quality of life of patients with this condition. To create a specific instrument to measure the impact of halitosis in the quality of life of individuals is of great importance, given how this condition affects significantly the quality of life of the people affect by it.

\section{REFERENCES}

1. Pham TA, Ueno M, Zaitsu T, Takehara S, Shinada K, Lam P.H, Kawahuchi Y. Clinical trial of oral malodor treatment in patients with periodontal diseases. J Periodontal Res. 2011;46(6):722-29.

2. Moreno T, Hass NA, Castro GD, Winter R, Oppermann RV, Rosing CK. Tratamento da periodontite agressiva e alterações nos compostos sulfurados voláteis. Rev Odonto Ciência. 2005; 20(49):217-21.

3. Domingos PAS, Abreu AC, Dantas AAR, Oliveira ALBM. Halitose: limitando a qualidade de vida. Rev. Odontol. Univ. São Paulo. 2011;23(2):171-81.

4. Zalewska A. et al. Halitosis-a common medical and social problem. Acta Gastroenterol Belg. 2012; 75(3):300-9.

5. Rosenberg M. Clinical Assessment of bad breath: current concepts. J Am Dent Assoc.1996; 127:475-82.

6. Morita M, Wang HL. Association between oral malodor and adult periodontitis: a review. J Clin Periodontol. 2001;28(9):813-19.

7. Figueiredo LC, Rosetti EP, Marcantonio E JR, Marcantonio RA, Salvador SL. The relationship of oral malodor in patients with or without periodontal disease. J Periodontol. 2002; 73(11):1338-42.

8. Gorender M, Kolbe A. Correlação entre halitose e esquiva social. Rev Bras Neurol Psiquiat. 2004; 8(2):68.

9. Scully C, Greenman J. Halitology: Breath odour: a etiopathogenesis and management. Oral Dis. 2012;18(4):333-45.

10. Calil C, Tarzia O, Marcondes F. Qual a origem do mau hálito? Rev Odontol UNESP. 2006; 35(2):185-90.

11. Cartaxo RO, Ferreira DAH, Padilha WWN. Influência social da qualidade do hálito. Rev Inic Cien Odontol.2008;6(2).

12. Associação Brasileira de Halitose (ABHA/ABPO). 2008.

13. Elias MS, Ferriani MD. Historical and social aspects of halitosis. Rev Lat Am Enfermagem. 2006;14(5):821-23.

14. Nadanovsky P, Carvalho LB, Ponce de Leon A. Oral malodour and its association with age and sex in a general population in Brazil. Oral Dis. 2007;13(1):105-9. 
15. Almas K, Albaker A, Felembam N. Knowledge of dental health and disease among dental patients: a multicenter study in Saudi Arabia. Indian J Dent Res.2000;11(4):145-55.

16. Sopapornamorn P, Ueno M, Shinada K, Vachirarojpisan T, Kawaguchi Y. Clinical application of a VSCs monitor for oral malodour assessment. Oral Health Prev Dent. 2006;4(2):91-7.

17. Eli I, Baht R, Koriat H, Rosenberg M. Selfperception of breath odor. J Am Dent Assoc. 2001;132(5):621-26.

18. Manual da Organização Mundial da Saúde, 1998. Who. The World Health Organization Quality of Life assessment (WHOQOL): position paper from the World Health Organization. Soc Sci Med. 1995;41(10):1403-9.

\section{CONFLICTS OF INTERESTS}

The authors declare no conflicts of interests.

\section{CORRESPONDING AUTHOR}

\section{Juliane Pereira Butze}

juliane.butze@fsg.edu.br 